\section{AIR LOAN SERVICE}

Assistant Secretary of Agriculture and Director of Science and Education George $\mathrm{L}$. Mehren and Pennsylvania Secretary of Agriculture Leland $\mathrm{H}$. Bull have announced inauguration of a daily round-trip interlibrary loan service by air between the National Agricultural Library in Washington, D.C., and the

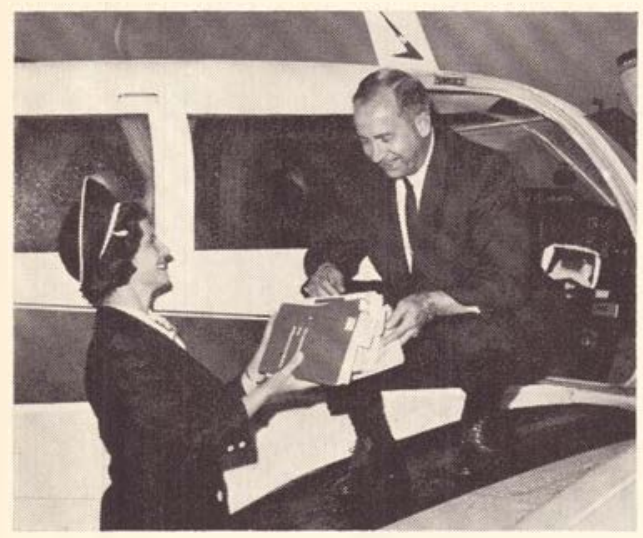

Mrs. Freeman and W. Carl Jackson

Pennsylvania State University library at University Park, Pa.

Mrs. Orville L. Freeman, wife of the Secretary of Agriculture, initiated the new agricultural library service in a ceremony at Page Airways, National Airport, Washington, D.C., at 5:15 p.m. April 17. She began the reciprocal service by sending off the first two books after a brief ceremony highlighting National Library Week.

According to Assistant Secretary Mehren, this cooperative agreement marks the first "flying books" service between a national library and a land grant university. Although the interlibrary loan service has been going on for years, time required to borrow a book often exceeded the time it was actually used. The new reciprocal service will permit delivery of publications to patrons at both locations well within twenty-four hours from the time a request is made.

Also participating in the ceremonies with Mrs. Freeman were W. Carl Jackson, Penn State University, director of libraries; Foster E. Mohrhardt, director of the National Agricultural Library, and assistant director for program coordination, Mrs. Blanche L. Oliveri, who developed the program for the department.

\section{TITLE I CONSTRUCTION GRANTS AND LOANS}

New federal grants and loans of more than $\$ 17$ million will help thirty-one colleges and universities build or remodel libraries in eighteen states, Puerto Rico, and the Virgin Islands. New and supplemental grants totaling approximately $\$ 11$ million were awarded to twentythree institutions for construction projects for libraries under Title I of the Higher Education Facilities Act, which provides for federal aid of up to one-third of the cost of academic construction at undergraduate schools and up to 40 per cent of construction cost at public community colleges and technical institutes. Under Title III of the Act, which provides for construction loans, eight colleges and universities received a total of almost $\$ 6$ million for library construction projects. *

The grants will support projects costing almost $\$ 47$ million and loans will support projects costing approximately $\$ 14$ million.

- In some projects, library construction is combined with other projects such as instructional, science or humanities, and administrative construction.

\section{HISTORY OF EDUCATION IN ITALY TO BE ISSUED}

Axrong the many serious points of destruction brought on by the flood in Florence last November was the historical Palazzo Gerini which houses the Museo Nazionale della Scuola, the only Italian museum of its kind. It contained in its collections, some of the richest and rarest European and world educational materials, and was dedicated to the history of education and teaching. The damaged contents, as well as murals, furnishings, and the exterior total to unknown millions of lire. About $66,400,000$ lire have been estimated as the cost of restoration.

This restoration was begun almost immediately. As one form of self-assistance, however, the Centro Didattico Nazionale di Studi e Documentazione of the Ministry of Public Instruction has announced that its numbered edition of a unique volume, which was begun sometime ago, will be published in the autumn of 1967. The first edition of this book, entitled XXV Secoli di Educazione e Scuola in Italia, will be approximately three hundred pages in length and it will be available through subscription. Historical in character with colored as well as black and white illustrations, it will 
include the story of twenty-five centuries of Italian education and schools, as reproduced directly from the Museo's most important material, some of which may never again be available in the original. There will be reproductions of works of art, rare documents, and a survey of modern educational institutions. The most interesting illustrations will be available as slides and will accompany the volume. This important publication should be of interest to most types of libraries and schools, as well as to teachers and scholars. The proceeds are to be used toward the restoration of the Museo. All subscribers will be listed in the volume.

Reservations may be made with the Centro Didattico Nazionale di Studi e Documentazione, Palazzo Gerini, Via Buonarroti, 10, Firenze, Italia. The volume with slides, postpaid, is priced at $\$ 10$, and will be mailed immediately upon publication. (Payment may be made to bank account 15-1, Agency A, Banco di Roma, Piazza Salvemini, Firenze, Italia, but addressed to the Centro Didattico Nazionale di Studi e Documentazione itself at the address given earlier. )-Anne V. Marinelli, Member of A.L.A. Special Committee to Aid Italian Libraries.

\section{CONTINUING MEMBERSHIP IN ALA}

Current members who have had 25 years of consecutive membership in ALA may apply for "Continuing Membership" at the time of permanent retirement. Continuing membership offers the same privileges as Personal membership without the annual payment of dues.

To check your eligibility and apply, please write:
Membership Records
American Library Association
50 East Huron Street
Chicago, Illinois 60611

\section{ITEMS AVAILABLE FROM ACRL}

The following items are available from the ACRL headquarters office of ALA. Except where prices are indicated, single copies are free. Orders for more than one copy will be billed at $20 \notin$ per copy.

Donald P. Hammer, "Automated Operations in a University Library-A Summary," Reprinted from College and Research Libraries, Volume XXVI, No. 1.

Robert B. Downs, "Crisis in Our University Libraries," Reprinted from College and Research Libraries, January 1961, Volume XXII, pages 7-10.

H. Vail Deale, “A Decade with MALC," Reprinted from November 1964, College and Research Libraries.

College and Research Libraries Five Year Index, Volumes XXI-XXV. $\$ 1.00$ per copy.

"Guidelines for Establishing Junior College Libraries," Reprinted from the November 1963, College and Research Libraries.

"Guidelines for Library Service to Extension Students," Reprinted from ALA Bulletin, January $1,967$.

Norman E. Tanis, "Implementing the Junior College Library Standards," Reprinted from the March 1961, College and Research Libraries.

Robert B. Downs and Robert F. Delzell, "Professional Duties in University Libraries," College and Research Libraries, January 1965.

Verner W. Clapp and Robert T. Jordan, "Quantitative Criteria for Adequacy of Academic Library Collections," Reprinted from College and Research Libraries. Vol. 26, No. 5.

"ALA Standards for College Libraries," Reprinted from College and Research Libraries, July 1959, Volume XX, pages 274-80.

"ALA Standards for Junior College Libraries," Reprinted from College and Research Libraries, May 1960, Volume XXI.

"Statement of Service to Library Users," Reprinted from ACRL News, April 1966.

Robert B. Downs, "Status of University Librarians-1964," Reprinted from July 1964, College and Research Libraries.

E. W. Erickson and LeMoyne W. Anderson, "Report of a Survey of the Western Washington State College Library," May 21-25. 1962. $\$ 2.50$ per copy. 